\title{
SEROLOGICAL AGGLUTINATION AND PRECIPITIN MECHANISMS IN RHEUMATOID ARTHRITIS
}

\author{
By Ellis Dresner, M.D., M.R.C.P., \\ Senior Staff Physician and Rheumatologist, Lemuel Shattuck Hospital, Boston, Massachusetts
}

\section{Streptococcal Agglutination}

In 1929 Cecil and his colleagues observed that the sera of patients with rheumatoid arthritis had the property of agglutinating a specific strain of haemolytic streptococcus in high titre, and as this property was not present in the sera of control subjects, concluded that it was a specific manifestation of the disease (Cecil et al., 1929, 193I). Later it was found that other strains of haemolytic streptococcus were also agglutinated by a high proportion of rheumatoid sera, but agglutinins were not found in cases of degenerative or other arthritis (Nicholls and Stainsby, 1931). The agglutinins were thought to be antibodies to a non-type-specific haemolytic streptococcal antigen, and their presence in rheumatoid sera was widely confirmed (Dawson et al., 1932a; Gray and Gowen, 1931 ; Kalbak, 1948; Keefer et al., 1933; Wainwright, 1934). Soon afterwards agglutinins active against $\mathbf{R}$ strains of pneumococci (Dawson. et al., I932a and b; Wallis, 1946b) and staphylococci (Oker-Blom, 1952a) were also found to be present in rheumatoid sera. It is generally accepted that the presence of agglutinins is related to the duration and severity of the arthritis, about 68 per cent. of patients having them at some time in the blood (Cecil and de Gara, 1946) and also in the synovial fluid (Levinthal, 1939).

These observations naturally led to a search for the presence of other streptococcal antibodies in the blood in rheumatoid arthritis, but significant titres of antistreptolysin $\mathrm{O}$ and antifibrinolysin, though present in proven haemolytic streptococcal infections and rheumatic fever, could not be found in rheumatoid arthritis (Myers and Keefer, I934; Myers et al., 1935; Perry, 1940; Ouchterlony and Palmborg, I949; Bunim and McEwen, 1940). Antihyaluronidase and antihaemolysin (Harris et al., 1950; Faber, 1953), and antistaphylolysin (OkerBlom and Widholm, 1952) were similarly absent.

Oker-Blom (r942a and b; Oker-Blom and Widholm, 1952), as a result of absorption studies of rheumatoid sera with streptococci, staphylococci, colloidal aluminium silicate and specific antibacterial immune sera, showed that agglutinating activity is specific for neither of the above organisms, and cannot be correlated with the serum concentrations of antibodies to them.

It is clear that the phenomenon of bacterial agglutination in rheumatoid arthritis is nonspecific with regard to the organisms agglutinated and that a bacterial antigen is not involved. In confirmation of this, Dawson et al. (1934) noted a tendency of rheumatoid sera to precipitate haemolytic streptococci in parallel to their ability to agglutinate them, and Chasis and McEwen $(1936)$ also found non-type-specific precipitins in rheumatoid sera active against crude streptococcal extracts, independently of the presence of agglutinins. Further light was thrown on the problem by Wallis (1946a), who showed that rheumatoid sera can agglutinate suspensions of collodion particles unsensitized with antigen. The collodionagglutinating factor is often present in high dilution, is not found in normal sera in significant amounts, is thermolabile, and appears to be a globulin.

For some time the properties of streptococcal. and collodion agglutination were used as diagnostic tests for rheumatoid arthritis, but have now been largely abandoned because of their failure in about one-third of cases, and technical difficulties involved in preparing stable and uniform test preparations.

\section{Sheep Cell Agglutination}

In I940 Waaler observed that sera from patients with rheumatoid arthritis agglutinated sheep erythrocytes, previously sensitized with a nonagglutinating amount of haemolytic amboceptor, in about 36 per cent. of cases, whereas less than 5 per cent. of non-rheumatoid sera possessed this property. Agglutination did not occur with unsensitized cells, and was therefore not due to 
heterophile antibody. The finding of an agglutinating factor in some sera against sensitized erythrocytes ('Agglutinationsfordende Substanz') had been previously noted by Meyer in 1922, but had not been related to rheumatoid arthritis. Then in 1948, Rose and others, whilst testing the serum of a convalescent from rickettsialpox with rheumatoid arthritis for complement fixation, found it to agglutinate sheep erythrocytes treated with rabbit antisheep cell amboceptor to a titre I28 times greater than that against unsensitized cells. This led to the development of a ' differential agglutination test ' with the result expressed as the quotient of the sensitized over the unsensitized cell titres. A positive result, arbitrarily taken as a differential titre of $I$ in 16 or greater, was present in 80 per cent. of adult rheumatoids arthritis tested, and in 7 per cent. of controls.

A modification of the Rose technique was devised by Heller et al. (1949) with the result expressed as the titre of agglutination of sensitized cells after prior removal of heterophile antibody by adsorption with sheep cells. By this method Heller claimed positive tests in 90 per cent. of cases of rheumatoid arthritis compared with 6r per cent. by the Rose differential technique. This gain in sensitivity was at the expense of some loss of specificity, but many workers found it the more advantageous method (Ball, J950).

A further modification of the Heller technique (Heller et al., 1952; Jacobson et al., 1953) uses the ratio between the differential agglutinating titres of test sera diluted in 5 per cent. sheep serum and in saline after preliminary absorption of heterophile, a ratio of 4 to $r$ or higher indicating a positive reaction.

In published reports of tests on rheumatoid sera using the Waaler-Rose or Heller methods or their modifications, the proportion of positive results varies from about 45 to as high as 90 per cent. in different series. Kellgren (1952) found 47 per cent. of his own series of 642 cases gave positive reactions, whilst Coggeshall (1953), in a review of 1,800 published cases, found an overall positive percentage of 64 . Greenbury et al. (1956) had 90 per cent. positive tests in 294 cases, and claim a rise to 95 per cent. in patients with radiological lesions. This wide variability in reported results is probably partly due to a lack of uniformity in diagnostic criteria. Results are much more frequently positive in unequivocal than in unselected cases (Ball, 1952; Alexander and de Forest, 1954), but the exclusion of doubtful cases gives a bias suggesting unmerited sensitivity of the test. Improvements in technique of performing the test are reported to give a higher percentage of positive results (Boisvert et al., 1956), but sensitivity can be raised only at the expense of specificity, as for example by increasing the amount of amboceptor used. An agglutinating system positive in 60-70 per cent. of rheumatoids is positive in up to 4 per cent. of controls. False positive readings are found most commonly in 'atypical' forms of rheumatoid arthritis (Ball, 1952). Positive results are rarely obtained in ankylosing spondylitis (I.5 per cent.), juvenile rheumatoid arthritis ( 13.5 per cent.), and psoriatic arthritis ( 7 per cent.), and almost never in rheumatic fever (Rose et al., 1948; Scott, 1952; Kellgren, 1952; Heller et al., 1952; Ball, 1952; Alexander and de Forest, 1954; Svartz and Schlossmann, 1950). The reported incidence of up to 3 per cent. positive tests in osteoarthritis is possibly due to the inclusion of some cases of mild or concealed rheumatoid arthritis. The condition other than rheumatoid arthritis most frequently giving a positive test is systemic lupus erythematosis, in which the incidence, when the standard methods are used, is possibly as high as in rheumatoid arthritis (Ball, 1952; Svartz and Schlossmann, 1950; Kellgren, 1952), and positive tests occur not infrequently in scleroderma and dermatomyositis (Alexander and de Forest, 1954; Dordick and Wasserman, 1950; Svartz and Schlossmann, 1952). Occasional positive tests are also reported in a variety of miscellaneous conditions (Greenbury et al., 1956). The test is not, as was originally thought, of value as an index of disease activity in rheumatoid arthritis, and, once positive, tends to remain so despite variations in the patient's clinical condition (Pike et al., 1953) or steroid therapy (Ball, 1952; Alexander and de Forest, 1954; Svartz and Schlossmann, 1950). Positive tests in rheumatoid arthritis are most likely to be found in males; in those with widespread disease of long standing; and especially in the presence of subcutaneous nodules (Kellgren, 1952). Although the test may become positive within a few weeks of the onset of the disease (Ball, 1952; Pike et al., 1953; Jawetz and Hook, 1949; Brown et al., 1949; Sulkin et al., 1949) it more usually does so after about a year, and its diagnostic value therefore fails in the earliest stages of the illness when laboratory confirmation of the diagnosis is most needed. When the agglutinating factor is present in the blood it is also found in the synovial fluid (Jacobson et al., 1953, 1956; Svartz and Schlossmann, 1950).

In general, the test as performed by the methods described has a high degree of specificity for rheumatoid arthritis and those conditions characterized histologically by the presence of fibrinoid, with the exception, as Kellgren points out, of rheumatic fever. Nevertheless, about one-third of all cases of arthritis are negative by these 
methods at any one time, and in seeking to explain this, Ziff and his colleagues (1954) considered the possible presence in rheumatoid serum of an agglutination inhibitor. Such an inhibitor was found in non-rheumatoid sera, and its partial separation from the agglutinating factor was achieved by the use of the euglobulin fraction of the serum precipitated by dialysis against phosphate buffer at pH 6. Agglutinating activity in the euglobulin fraction was 92 per cent. positive, compared with 78 per cent. positive in whole serum in 83 cases of rheumatoid arthritis, and the incidence of positive reactions in control sera was reduced from 13 per cent. to 2 per cent. Virtually complete removal of the hypothesized inhibitor was demonstrated by the finding of 100 per cent. failure to inhibit the agglutination of known positive serum by rheumatoid euglobulin fractions, whereas only 5 per cent. of control sera behaved in this way. Thus failure of the euglobulin concentrate of rheumatoid serum to inhibit agglutination provides a more sensitive index of agglutinating activity than does the direct test for agglutination. It is of interest that by the euglobulin test 6 out of 12 cases of juvenile rheumatoid arthritis had positive agglutination, an incidence much higher than that reported by the standard tests in this condition; and all 12 showed failure to inhibit agglutination. This latter finding can be interpreted as indicating the test to be positive in all cases. All of I I patients with ankylosing spondylitis and 6 patients with psoriatic arthritis were negative both as regards the presence of agglutinator and the absence of inhibitor, in sharp contrast to the uniformly positive results in adult and juvenile rheumatoid arthritis, including 6 early cases. Although 3 of 7 cases of disseminated lupus erythematosis had positive tests on their whole sera, in only one was the euglobulin fraction active in causing agglutination and failing to inhibit agglutination in known positive sera, and this particular case had clear evidence of rheumatoid arthritis in addition to lupus. Use of the euglobulin fraction to reduce the number of false positive reactions has been confirmed (Bernstock et al., 1956). The presence of a serum agglutination inhibitor was also discovered independently by Heller et al. (1954) in Cohn's fraction II. Ziff and his colleagues found inhibitor in pooled human gamma globulin which was active in vivo in inhibiting the agglutination reaction, and in causing inhibition of the reaction to reappear in rheumatoid sera (Ziff et al., 1956). Cold precipitation of serum as a means of fractionation yields a globulin of high activity (Svartz and Schlossmann, 1955) and appears to be almost as effective as dialysis in removing inhibitor and factors giving false positive reactions.
Nature of the Reaction

That the reaction is of aetiological importance in rheumatoid arthritis seems probable because of its high degree of specificity in the adult and juvenile forms of the disease and its absence in the pathologically-related conditions, ankylosing spondylitis and psoriatic arthritis, when serum fractionation techniques are used. The persistence of the reaction during spontaneous and hormonally-induced remissions, when other indices of disease activity have reverted to normal, is additional evidence that it cannot reasonably be thought to be a non-specific manifestation of synovial inflammation.

Waaler (1940) considered the rheumatoid factor to be an intensification of an agglutination activator normally present in serum, and found it to be thermostable and precipitable with globulin on ammonium chloride fractionation. Rose et al. (1948) and Thulin (r955) located it in the betagamma globulin fraction by electrophoresis, and Heller et al. (1954) in Cohn's fraction II (gamma globulin). Robinson et al. (1954) fractionated serum protein by dialysis against phosphate buffer and found maximum activity in the beta-globulin component, but Lamont-Havers (1953) found a water-precipitated gamma globulin to contain the active factor. The cold-precipitated active fraction of Svartz and Schlossmann (1955) is also a gamma globulin, but as the result of zone electrophoresis studies on starch columns Svartz (1956) believes some activity is due also to a fraction in the beta region. By ethanol precipitation of serum, Heller et al. (1955) found activity specifically in fraction III, predominantly beta globulin, although there is no correlation between betaglobulin concentration and agglutinating activity. By the combined use of a number of fractionation techniques, Lospalluto and Ziff (1956) have purified the agglutinating factor more than five hundredfold over the original serum, and show the presence of two components with mobilities in the gamma-globulin range. They have made a preliminary chemical characterization of the factor and also of serum inhibitor, which they show to be present in all human sera, but in insufficient amounts in rheumatoid sera to modify its agglutinating titre. Agglutinating activity is destroyed by bacterial contamination (Jawetz and Hook, I949) and by lyophilization (Robinson et al., 1954), but is otherwise stable for years. Attempts to remove the factor by adsorption on to sensitized cells have met with little success (Waaler, 1940; Pike et al., 1953; Winblad, 1952a), and it is not adsorbed by barium sulphate, asbestos, or filter paper (Vaughan, I955), but precipitates with the beta globulin when serum is treated with aluminium silicate (Thulin, r955). 
The factors causing bacterial and cellular agglutination are distinct, and can be separated by absorption methods (Pike et al., 1949a and b) and by electrophoresis (Thulin, I955).

Systems other than the sheep cell-rabbit amboceptor can be used to detect agglutination (Wager, 1950; Winblad, 1952a; Shichikawa et al., 1956a); horse, ox, goat, cow, chicken and guinea-pig cells, and even washed erythrocyte stroma (Svartz and Schlossmann, I955) can be sensitized with homologous rabbit antiserum; or homologous guineapig antiserum may be substituted. Pike et al. (I949a and b) state that sensitized rat and human group $O$ cells do not detect agglutination, but this is disputed (Wager, 1950; Foz et al., 1954). Rheumatoid serum does not enhance the agglutination by normal human or infectious mononucleosis sera, or by anti-Rh serum with sensitized $\mathrm{Rh}$-positive cells; it is not an enhancer of nonspecific agglutination.

The agglutinating factor has many of the features of an antibody to an unknown antigenic stimulant, such as its location in the antibody fraction, its stability, and its enhancement by non-immune serum and pooled human plasma (Winblad, I952b; Plotz, 1953). The effect of globulin fractions of normal sera in enhancing agglutination by specific immune sera has been known for many years (Pike et al., 1949b). The apparent lack of immunological specificity of the reaction, both as regards the type of cells agglutinated and the source of amboceptor, suggests that if this is an immune reaction the antibody concerned cannot be specific for erythrocytes, which may serve rather as an inert carrier than as the source of antigen. That this is indeed so was shown by Heller et al. (1954), who demonstrated that tannic acid-treated erythrocytes, when coated with human serum fraction II, are agglutinated by active rheumatoid sera. Erythrocytes can, in fact, be eliminated from the system entirely as Vaughan (1955) has shown that the rheumatoid factor is active in non-agglutinating systems and can be adsorbed on the washed immune precipitates from the antisera of rabbits immunized with crystalline egg albumin, although it cannot be adsorbed by barium sulphate. A system consisting of Brucella abortus sensitized with a human anti-Brucella serum will also detect the rheumatoid factor (Foz et al., I954); and polystyrene latex particles coated with pooled gamma globulin will also serve as a carrier mechanism (Plotz and Singer, 1956). Further, sera agglutinating human fraction II-coated cells will precipitate with pooled human serum fraction II, but the reaction is inhibited by excess of fraction II (Epstein et al., r956). If the agglutinating factor is a component of an immune precipitin reaction the antigen must necessarily be a gamma-globulin constituent common to many species.

Speculation has arisen as to whether the agglutinating factor could be a complement (Meyer in 1922 assumed that his 'Agglutinationsfordende Substanz' was the third component of complement, the only thermostable component then known), and this role has been recently examined (Hobson and Gorrill, 1952; Gorrill and Hobson, 1952). Hobson and Gorrill claim that the agglutinating factor present in small amounts in normal sera resides in the fourth component of complement $\left(\mathrm{C}_{4}\right)$ and that the first component $(\mathrm{Cr})$, after heating, inhibits the agglutinating activity of $\mathrm{C}_{4}$. The $\mathrm{C}_{2}$ and $\mathrm{C}_{4}$ components of active rheumatoid sera behave in the same way, but in them the lytic titre of $\mathrm{C}_{4}$ is about three times as great as normal. This would inferentially relate the increased lytic titre of $\mathrm{C}_{4}$ to agglutinating activity. Identification of lytic activity with complement is denied by Ball (1952a) and by Bunim (1953), but Shichikawa et al. (1956b and c), although unable to relate agglutinating activity to $\mathrm{C}_{3}$ or $\mathrm{C}_{4}$, found some tentative relationship with $\mathrm{Cr}$. The elevation of complement that occurs in the sera in many connective tissue disorders (Wedgewood and Janeway, 1953) and in about one-third of cases of rheumatoid arthritis (Vaughan et al., I95 I) is not generally correlatable with agglutinating activity of whole serum. However, the actual fractions of complement elevated in these disorders is not known.

A theory that the rheumatoid factor might be an auto-antibody is rejected by Svartz (1956) on the grounds that it is not adsorbed with erythrocytes, whether coated with globulin or not; positive sera do not give a positive antiglobulin test ; and steroids fail to lower its titre. Haemagglutination is inhibited in vitro by sulphonamides, especially azetazolamide, but only at non-therapeutic levels. The significance of this finding is not clear.

\section{Conclusions}

It seems clear that in both the sensitized sheep cell and the streptococcal agglutination tests the cells and organisms have no immunological function but serve as inert carriers of a globulin constituent of serum; in the case of the sheep cells, of a gamma globulin in the amboceptor, and in the streptococci, of a water-soluble pseudoglobulin (Lamont-Havers, I955), possibly a beta globulin (Oker-Blom, 1952b). Cohn fraction II of serum-gamma globulin-in excess can inhibit agglutination or reduce the titre of a positive serum, presumably by competition with the rheumatoid factor for the globulin reactant on the carrier. This reactant or 'antigen' is therefore 
a constituent of normal human gamma-globulin and also of the antisera to a wide range of antigenic stimulants.

The agglutinating factor or 'antibody' has been variously located in the beta- and gammaglobulin components of sera fractionated by different methods, and its chemical nature is not yet known although some preliminary data have accrued (Lospalluto and Ziff, I956). The evidence at present is against it being a fraction of complement. The agglutinating factor for streptococci is a euglobulin (Lamont-Havers, 1955) distinct from the agglutinating factor for sheep cells. An inhibitor to the sheep-cell agglutinating factor is present in all sera, but in rheumatoid arthritis in amounts too small to reduce the agglutinating titre. Its absence is probably of diagnostic significance.

Tannic acid-treated and fraction II-coated erythrocytes will absorb both the sheep-cell and streptococcal factors from serum, but amboceptorsensitized cells will not, and the sheep-cell factor is not removed by prior absorption of positive serum with streptococci. It is clear, therefore, that separate reactors, or different fractions of the same reactor, are involved in the two tests.

If the character of the 'antigen' in 'human gamma globulin and antisera which reacts with the abnormal globulin component in the blood of subjects with rheumatoid arthritis is elucidated, it may support the belief that a true immune reaction is concerned, involving an unknown component of the host's connective tissuespossibly of a non-protein nature in combination with a constituent of serum protein. Thulin (1955) suggests that, because treatment of rheumatoid sera with a variety of mucopolysaccharides and autoclaved synovial tissue reduces or abolishes its titre for agglutinating streptococci, there exists in these sera auto-antibodies reacting with antigenically active depolymerized mesenchymal polysaccharides bound to serum proteins. Evidence that immune reactions of this nature can occur is at present slight, but investigation of the immunological reactivity of tissue polysaccharides is being pursued (Boake and Muir, 1955; Glynn and Holborrow, I952; Steffen and Schindler, 1955) and seems to offer a likely field for the further investigation of the pathogenesis of certain rheumatic diseases.

\section{BIBLIOGRAPHY}

ALEXANDER, R., and DE FOREST, G. K. (r954): Amer. F. Med., 16, 191 .

BALL, J.'(I950): Lancet, ii, 520.

BALL, J. (1952): Ann. Rheum. Dis., II, 97.

BALL, J. (1952a): Lancet, i, 6r4.

BERNSTOCK, L., BEDSÓN, H. S., and GLYN, J. H. (1956) Brit. med. f., i, 1151 .

BOAKE, W. C., and MUIR, H. (1955): Lancet, ii, 1222.

BOISVERT, P.' L., BROCKETT, J. B., and DE FOREST, G. (1956): Yale F. Biol. Med., 28, 622.
BROWN, R., BUNIM, J. J., and MCEWEN, C. (1949): Ann Rheum. Dis., 8, 299.

BUNIM, J. J. (1953): Ibid., 13, 321 .

BUNIM, J. J., and MCEWEN, C. (1940): \%. clin. Invest., 19, 75. CECIL, R. L., and DE GARA, P. F. (1946): Amer. F. med. Sci.,

CECIL, R. L., NICHOLLS, E. E., and STAINSBY, W. J. (1929): Arch. intern. Med. 43, 571 .

CECIL, R. L., NICHÖLLS, E. E., and STAINSBY, W. J. (1931):

Amer. $₹$. med. Sci., I8I, I2.

COGGESHALL H. C. (1953): Ann. Rheum. Dis., 12, 321.

DAWSON, M. H., OLMSTEAD, M., and BOOTS, R. H. (1932a):

DAWS. Immunol., 23, 187. Ibid., 23, 205.

DAWSON, M. H., OLMSTEAD, M., and JOST, E. L. (1934):

Ibid., 27, 355. clin. Path., 20, 526.

EPSTEIN, W., JOHNSON, A. M., and RAGAN, C. (1956): Proc. Ann. Meet. A.R.A., Chicago, June 1956.

FABER, F. (1953): Acta med.' Scand., $147,121$.

FOZ, A., and BATALLA, E. (1955): Rev. esp. Rheum., 6, 142

FOZ, A., BATALLA, E., and ESPACIO, L. (1954): Rev. Diagn. biol. (Madr), 3,460 .

GLYNN, L. E., and HOLBORROW, E. J. (1952): Lancet, ii, 449. GORRILL, R. H., and HOBSON, D. (1952): $\mathcal{f}$. path. Bact.,

GRAY, W. J., and GOWEN, C. H. (1931): Amer. F. med. Sci., 182,682 .

GREENBURY, C. L., HILL, A. G. S., SMITH, R. S., and GOOD, M. S. (1956): Lancet, i, 544

HARRIS, T. N.. HARRIS, S., DANNENBERG, A. R., and HOLLANDER, J. L. (1950): Ann. intern. Med., 32, 917.

HELLER, G., JACOBSON, A. S., and KOLODNY, M. H. (1949): Proc. Soc. exper. Biol. E' Med., 72, 316.

HELLER, G., JACOBSON, A. S., KOLODNY, M. H., and KAMMERER, W. H. (1954): Ұ.' Immunol., 72, 66.

HELLER, G. JACOBSON, A. S.; KOLODNY, M. H., and SCHUMÄN, R. L. (1952): Ibid., 69, 27.

HELLER, G., KOLODNY, M. H., LEPOWW, I. H., JACOBSON, A. S., REVERA, M. E., and MARKS, G. H. (1955): Ibid., $74,340$.

HOBSON, D., and GORRILL, R. H. (1952): Lancet, i, 389

JACOBSON, S., KAMMERER, H., and HELLER, G. (1953): Ann. Rheum. Dis., 12, 321 .

JACOBSON, A. S., KAMMERER, W. H., WOLF, J., EPSTEIN, W. V., and HELLER, G. (1956): Amer. Y. Med., 20, 490.

JAWETZ, E., and HOOK, E. V. (1949): Proc. Soc. exper. Biol. $₹$ Med., 70, 650 .

KALBAK, K. (1948): Acta med. Scand., 130, 358.

KEEFER, C. S., MYERS, W. K., and OPPEL, T. W. (1933): F. clin. Invest., 12, 279.

KELLGREN, J. H. (1952): Brit. med. F., i, 1093, 1152.

LAMONT-HAVERS, R. W. (1953): Ann. Rheum. Dis., 13, 32 I. LAMONT-HAVERS, R. W. (1955): Proc. Soc. exper. Biol. E

LOSPALLU' 88, 35. J., and ZIFF, M. (1956): Proc. Ann. Meeting A.R.A., Chicago, June 1956 .

LEVINTHAL, W. (1939): Ann. Rheum. Dis., 1, 67.

MEYER, K. (1922): Ztschr. f. Immun. u. exper. Therap., 33, 283. MILLER, J. E., LYNCH, E. R., and LANSBURY, J. (1949): F. Lab. \&5 clin. Med., 34,1216 .

MYERS, W. K., and KEËFER, C. S. (1934): ₹. clin. Invest., I3, 155. MYERS, W. K., KEEFER, C. S., and HOLMES, W. F. (1935):

Ibid., 14, Ir9. OKER-BLOM, N." (1952a): Ann. Med. exp. Biol. Fenn., 30, 139.

OKER-BLOM, N. (1952b): Ibid., 30, 150 .

OKER-BLOM, N., and WIDHOLM, O. (1952): Ibid., 30, 144.

OUCHTERLONY, O., and PALMBORG, G. (1949): Rheumatism, PERRY ${ }^{28 .}$.

PERRY, C. B. (ro4o): Ann. Rheum. Dis., 2, 147.

PIKE, R. M., SULKIN, S. E., and COGGESHALL, H. C. (1949a): अ. Immunol., 63, 44I.

PIKE, R. M., SULKIN, S. E., and COGGESHALL, H. C.

PIKE, R. M. Sid. 63 , 447 , S. E., COGGESHALL, H. C., and BURDETTE, R. I. (1953): भ.' Lab. clin. Med., 4I, 880.

PLOTZ, C. M. (1953): Ann. Rheum. Dis., 13, 321.

PLOTZ, C. M., and SINGER, J. (1956): Proc. Ann. Meeting A.R.A. Chicago, June 1956 .

ROBINSON, A. R., STULBERG, C. S., and KUYPER, A. C.

(I954): Proc. Soc. exper. Biol. 'E5 Med., 85, 4 . (1948): Ibid., 68, I.

SCOTT, F E. T. (1952): Lancet, 1, 392.

SHICHIKAWA, K., ASANO, N., ORIHARA, M., MAYEDA, A., TAMATANI, Y., and YASUDA, J. (1956): Acta Rheum.

Scand., 23, 34.
SHICHIKAW., et al. (1956b): Ibid., 2, 45.

SHICHIKAWA, K., et al. (1956c): Ibid., 2, 55 .

STEFFEN, C., and SCHINDLER, H. (I955): Scheverz. Z. allg. Path. Bakt., 18, 287.

Bibliography continued on page 192. 
Clinical examination showed vague tenderness in the right half of the abdomen, maximum in the right iliac fossa. A tender mass was palpable in the region of McBurney's point about 2 in. in diameter. Temperature was $99^{\circ}$ and pulse rate 80 .

Laparotomy under general anaesthesia showed a tumour in the posterior wall of the caecum at the level of the ileo-caecal valve. The caecum was adherent to the posterior abdominal wall. A right hemi-colectomy was carried out with resection of the terminal ileum, caecum and ascending colon, and an end-to-end anastomosis was performed. Post-operatively the patient made a satisfactory recovery.

The specimen (Figs. 3 and 4 ) showed an ulcer about $r$ in. in diameter with vertical walls, penetrating deeply into the muscular layer of the bowel.

Further investigations showed no evidence of amoebiasis or other exciting cause.

Histological examination of both specimens showed no evidence of malignancy. In the first patient there was marked oedema in the submucous layer. The inflammatory processes were most marked in the depths of the ulcer, suggesting that the process of penetration was still active and that an abscess was probably about to form. The sub-mucous oedema is clearly shown in the section (Fig. 2). In the male patient there was no gross oedema in the sub-mucous layer, but inflammatory processes were rather more active. The ulcer had not penetrated so deeply, but the muscle had actually been partly breached. The histological picture is shown in Fig. 5.

\section{Comment}

It will be noted that both these cases were diagnosed as appendicitis and that the true pathology was only detected at operation. This appears to be the usual state of affairs with simple ulcers in the colon. In both specimens it was very noticeable that the inflammatory process was active

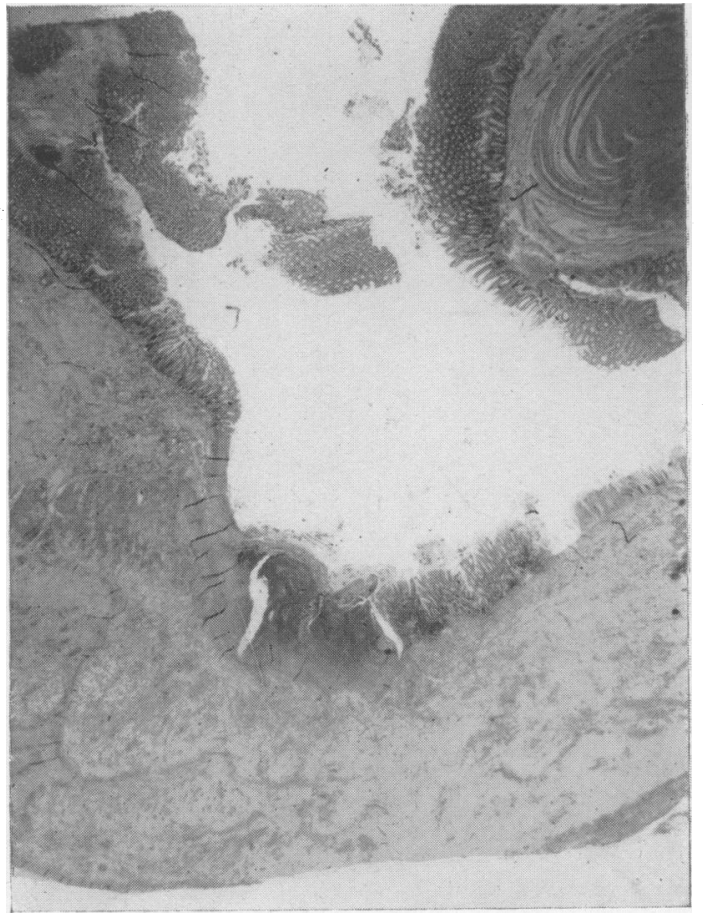

FIG. 5.

in the sub-mucous layer. As Cameron noted, this is a feature which has been seen by all observers reporting this condition in the past and it would, therefore, seem that the lesion is primarily one of the superficial layers in the bowel.

I should like to thank Dr. D. Brewer for the microphotographs and histological reports and Mr. T. F. Dee for Figs. 1, 3 and 4.

\section{BIBLIOGRAPHY}

CAMERON, J. R. (1939), Brit. F. Surg., 26, 526. WATTS, G. T. (1955), Postgrad. med. F., 31, 414.

Bibliography continued from page 174-Ellis Dresner, M.D., M.R.C.P.

SULKIN, S. E., PIKE, R. M., and COGGESHALL, H. C. (1949): Proc. Soc. exper. Biol. छீ Med., 70, 475.

SVARTZ, N. (1956): Lancet, ii, 194.

SVARTZ, N., and SCHLOSSMANN, K. (1950): Ann. Rheum. Dis., 9, 377.

SVARTZ, N., and SCHLOSSMANN, K. (1952): Act. med. Scand., 142,420 .'

SVARTZ, N., and SCHLOSSMANN, K. (1955): Ann. Rheum. Dis., $14,191$.

THULIN, K. E. (1955): Acta Rheum. Scand., 1, 22.

VAUGHAN, J. N. (1955): Ann. Rheum. Dis., 14, 431.

VAUGHAN, J. H., BAYLES, T. B., and FAVOUR, C.B. (1951): Amer. Y. med. Sci., 222, 186.
WAALER, E. (1940): Acta path. et Microbiol. Scand., 17, 172. WAGER, O. (1950): Ann. Med. exp. Fenn., 28, Suppl. 8. WAINWRIGHT, C. W. (1934): F. Amer. med. Ass., 103, 1357. WALLIS, A. D. (1946a): Amer. F. med. Sci., 212, 716. WALLIS, A. D. (1946b): Ibid., 212, 718. WEDGEWOOD, R. J. P., and JANEWAY, C. A. (1953): Pediatrics, II, 569.

WINBLAD, S. (1952a): Acta med. Scand., 142, 450.

WINBLAD, S. (1952b): Ibid., 142, 458.

ZIFF, M., BROWN, P., BADIN, J., and MCEWEN, C. (1954): Bull. Rheum. Dis., 5, 75.

ZIFF, M., BROWN, P., LOSPALLUTO, J., BADIN, J. and MCEẄEN, C. (1956): Amer. Ұ. Med., 20, 500. 